\title{
Lungun og loftgæðin
}

Mikil umræða hefur verið um heilbrigðismál að undanförnu enda verkefnin ærin og mörg hver býsna flókin. Langvarandi fjárskortur hefur einnig hindrað eðlilega frampróun.

Um pessar mundir eru 30 ár frá stofnun Félags íslenskra lungnalækna. Við pessi tímamót er gott að staldra við og líta um öxl en einnig að horfa til framtíðar. Fyrsti formaður félagsins var Porsteinn Blöndal og var hann einnig forseti fyrsta norræna lungnalæknapingsins sem haldið var hér á landi í júní 1990. Pingið var vel sótt og margir ungir læknar kynntu parna sínar fyrstu vísindarannsóknir sem unnar voru undir handleiðslu peirra sem eldri voru og reyndari. Jákvætt og hvetjandi andrúmsloft varð til pess að vekja áhuga á greininni og jók nýliðun og áhuga á rannsóknum. Sama ár var Félag evrópskra lungnalækna (European Respiratory Society, ERS) stofnað. Ping ERS eru haldin árlega og sækja pau að jafnaði 15.-20.000 manns.

Miklar framfarir hafa orðið í greiningu og meðferð lungnasjúkdóma á undanförnum árum. Einstaklingar með alvarlega lungnasjúkdóma eiga nú í meira mæli möguleika á að njóta sérhæfðrar pjónustu lungnahjúkrunarfræðinga og lækna heima í stað pess að koma á bráđamóttöku eða leggjast inn á Landspítala.

Að sama skapi hafa framfarir orðið í súrefnismeðferð með tilkomu ferðasúrefnisbúnaðar sem auðveldar súrefnisnotendum að dvelja utan heimilis og sinna áhugamálum sínum og ferðast jafnvel erlendis. Nýlega kynnti heilbrigðisráðherra að auknu fjármagni verði varið til pessa verkefnis og allt að 250 ferðasúrefnissíur verði nú aðgengilegar peim sem pess purfa. Samtök lungnasjúklinga eiga hrós skilið fyrir baráttu sína og prautseigju í pessu máli.

Mikil bylting hefur átt sér stað í meðferð alvarlegs astma með tilkomu líftæknilyfja. Tæplega 200 manns eru nú á líftæknilyfjameðferð vegna alvarlegs astma á Íslandi. Meðferð með anti-interleukin (IL)5 lyfjum, svo sem mepolizumab og reslizumab, og anti-IL-5 viðtaka $\alpha$, benralizumab auk anti-IgE lyfja eins og omalizumab hafa gjörbreytt lífi einstaklinga með alvarlegan astma. Mest munar um pátt lyfjanna í pví fækka astma versnunum um meira en helming. Með pessari meðferð má draga úr eða jafnvel hætta meðferð með sykursterum í töfluformi. Gera má ráð fyrir að fleiri lyf bætist í pennan hóp á næstu árum.

Nýir meðferðarmöguleikar hafa komið fram í meðferð lungnaháprýstings sem bætt hafa horfur og líðan. Вæði er hægt að víkka út æðar með præðingu og einnig hafa fjöldamörg lyf komið til sögunnar.

Jáeindaskanni hefur bætt greiningu lungnakrabbameina á frumstigi og pannig bætt horfur til lengri tíma. Nýjungar í skurðtækni hafa bætt lífsgæði peirra sem purfa á skurðaðgerð að halda. Ný lyf sem hafa áhrif á ónæmiskerfið hafa bætt horfur peirra sem hafa útbreiddan sjúkdóm.

Einstaklingar sem greinast með lungnatrefjun eiga einnig möguleika á sérhæfðari meðferð en áður sem bætir lífslíkur og dregur úr steragjöf.

Ýmsar ógnanir í loftslagsmálum munu skapa áskoranir fyrir lungnalækna á næstu árum eins og fram kom á málpingi Félags íslenskra lungnalækna á Læknadögum nýlega. Líklegt er að loftmengun af mannavöldum eða vegna náttúruhamfara, eldgosa og gróðurelda, auki tíðni öndunarfæraeinkenna og lungnasjúkdóma. Hér á landi er loftmengun vegna landrofs og gróðureyðingar ásamt útblæstri frá jarðhitaorkuverum sérstakt áhyggjuefni.

Fjöldi nýlegra rannsókna benda einnig til pess að rafrettur valdi alvarlegum lungnasjúkdómum sem jafnvel geti verið lífshættulegir. Mikilvægt er að börn og unglingar verði ekki markhópar í markaðssetningu á rafrettum og heilbrigðisyfirvöld purfa að taka af markaði bragðefni í rafrettuvökva en peim er einkum ætlað að höfða til barna.

Nýir smitsjúkdómar eins og kóróna-veirur í Kína sem valda lungnabólgu eins og nýlega hefur verið í fréttum munu auka enn frekar á áskoranir í lungnalækningum.

Samtök evrópska lungnalækna hafa nýlega hafið gerð fjölpjóða gæðagagnagrunna (ERS clinical research collaborations) með pað markmiði að fyrirbyggja og minnka pjáningar vegna öndunarfærasjúkdóma. Pessi vinna er unnin í nánu samstarfi við Evrópusamtök lungnasjúklinga ELF. Samvinna heilbrigðisstétta og samnýting upplýsinga frá gagnagrunnum jafnvel

pjóða á milli og aukin áhrif sjúklinga mun ýta undir framfarir og bæta meðferð.

Verkefni lungnalækninga eru fjölbreytt og spennandi. Nýjungar í lyfjameðferð og ný nálgun við meðferð sjúkdóma með einstaklingsmiðaðri meðferð hefur breytt lífi margra til betri vegar. Allir eiga rétt á að lifa og starfa í heilsusamlegu umhverfi en einnig að njóta bestu fáanlegrar heilbrigðispjónustu. Раð verður pví mikil pörf fyrir fleiri lungnalækna til að takast á við spennandi verkefni á næstu árum.

Verum pakklát forverum okkar sem með ötulu starfi sínu á undanförnum áratugum hafa lagt traustan grunn að starfi komandi kynslóða.

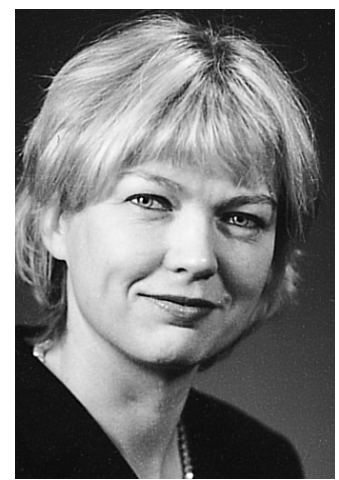

Dóra

\section{Lúơvíksdóttir}

lungna- og ofnæmislæknir Landspítala Fossvogi, formaður Félags íslenskra lungnalækna

doralud@landspitali.is

Fulltrúi Íslands í Nordic Severe Asthma Network (NSAN) Pátttakandi i ERS og á sæti í SHARP: - Severe Heterogenous Asthma Research collaboration, Patient-centered.
Climate change and
respiratory diseases

Dóra Lúðvíksdóttir MD, PhD Specialist in Pulmonary Medicine and Allergology Dept. of Allergy, Respiratory Medicine and Sleep Landspitali University Hospital

Reykjavik Iceland

DOI: 10.17992/lbl.2020.02.370 